\title{
Metamaterial-based Printed Circuit Antenna for Biomedical Applications
}

\author{
Dhulfiqar Ali ${ }^{1}$, Taha A. Elwi ${ }^{2}$, Serkan Ozbay ${ }^{3 *}$ \\ ${ }^{1}$ Gaziantep University, Faculty of Eng., Department of Electrical and Electronics Eng., Gaziantep, Turkey (ORCID: 0000-0002-2742-4511), thualfegar@gmail.com \\ ${ }^{2}$ Al-Ma'moon University College, Communication Engineering Department, Baghdad, Iraq (ORCID: 0000-0002-8389-5457), taelwi82@ gmail.com \\ 3* Gaziantep University, Faculty of Eng., Department of Electrical and Electronics Eng., Gaziantep, Turkey (ORCID: 0000-0001-5973-8243), sozbay@ gantep.edu.tr
}

(3rd International Congress on Human-Computer Interaction, Optimization and Robotic Applications June 11-13, 2021)

(DOI:10.31590/ejosat.950318)

ATIF/REFERENCE: Ali, D., Elwi, T. A., Ozbay, S., (2021). Metamaterial-based Printed Circuit Antenna for Biomedical Applications. European Journal of Science and Technology, (26), 12-15.

\begin{abstract}
Due to the rapid increase for novel antenna designs to satisfy the modern wireless technologies, different techniques are proposed to improve their performance. For this purpose, this paper presents a novel technique to design a miniaturized microstrip antenna structure based on metamaterial (MTM) transmission line defected patch. The proposed antenna is introduced as part of wearable systems with minimum back radiation toward the human body. Therefore, the antenna is constructed of a closed loop linked to an interdigital capacitor to magnify the electric field fringing at the patch core. The proposed antenna when printed on a FR-4 substrate at $0.6 \mathrm{GHz}$ in the first mode shows $S_{11}$ impedance matching less than -10dB. The proposed antenna performance is evaluated numerically based on CST MWS in terms of radiation pattern. A neural network is invoked to optimize the proposed antenna performance at the required frequency band. Finally, the proposed antenna performance is validated using another software package based on HFSS simulator to provide good agreement with percentage of error less than $4.4 \%$.
\end{abstract}

\section{Biyomedikal Uygulamalar için Metamalzeme Bazlı Baskılı Devre Anteni}

$\ddot{O} \mathbf{z}$

Modern kablosuz teknolojileri gereksinimleri için yeni anten tasarımlarının hızla artması nedeniyle, performans iyileştirme adına farklı teknikler önerilmektedir. Bu amaçla, bu makale, metamalzeme (MTM) tabanlı minyatür bir mikroşerit anten yapısı tasarlamak için yeni bir teknik sunmaktadır. Önerilen anten, insan vücuduna doğru minimum geri radyasyonla giyilebilir sistemlerin bir parçası olarak önerilmektedir. Bu nedenle anten, yama çekirdeğindeki elektrik alanı saçaklarını büyütmek için bir interdijital kapasitör ile bağlantılı kapalı bir döngüden yapılmıştır. Önerilen anten, birinci modda 0.6GHz'de bir FR-4 substratı üzerine basıldığında,-10dB'den daha az $S_{11}$ empedans eşleşmesini gösterir. Önerilen anten performansı, radyasyon modeli açısından CST MWS'ye dayalı olarak sayısal olarak değerlendirilmiştir. Önerilen anten performansını gerekli frekans bandında optimize etmek için bir sinir ağ oluşturulmuştur. Son olarak, önerilen anten performansı, \%4,4'ten daha az hata yüzdesi ile iyi bir uyum sağlamış ve bu değerler HFSS simülatörüne dayalı başka bir yazılım paketi kullanılarak doğrulanmıştır.

Anahtar Kelimeler: CST MWS, Sinir ağı, Biyomedikal, MTM, HFSS.

*Corresponding Author:sozbay@gantep.edu.tr 


\section{Introduction}

Metamaterials (MTM) were first proposed by Viktor Veselago in 1967 [1]. Artificial materials with nontraditional properties [2] may be used to characterize such structures. Negative permittivity and negative permeability are properties of these materials that enable electromagnetic waves to propagate backwards [3]. Pendry [4] proposed an interesting subwavelength feature that was realized as a split ring resonator (SRR) in 1999 to achieve negative permeability. SRR is essentially an LC circuit tank with equal inductance (L) and capacitance $(\mathrm{C})$ between two concentric rings resonating at a particular frequency [4]. The changes in scattering parameters (S-parameters) with respect to the introduction of a sample under test (SUT) can be transferred via a certain algorithm to retrieve the materials characterizations in this step. Microwave sensing is a proven tool for liquid characterization that has been used for over a decade [5]. Researchers have been involved in SRRs [6], complementary SRRs (CSRRs) [3], open CSRRs (OCSRRs) [4], closed ring resonator [5], and other miniaturized microwave resonators [6] based on transmission lines for biomedical applications [6]. The electromagnetic properties of these structures are affected by the frequency at which they operate and how the consistency factor varies with different liquid introductions [7]. Liquid characterizations can be discussed by calculating S-parameter coefficients and complex dielectric parameters of SUT [8]. This has offered the biological, pharmaceutical, and fuel industries a new sensing network [9]. The vast majority of microwave biological sensors are installed in ultra-thin cylindrical pipes [10] or slotted cylindrical tubes [11]. Materials under test losses can be extracted for quality detection by measuring S-parameter magnitudes at a specific frequency [12]. However, due to the problem of skin depth penetration, such technology has been found to be a major concern in the resolution of high-losses [13].

In this paper, a novel antenna design is suggested for biomedical applications based on a single port antenna element and MTM transmission line structure is proposed. The MTM is made up of a closed loop ring and an interdigital capacitor framework. The proposed structure is described in Section 2 with all geometrical descriptions. The parametric research and the analysis process are also discussed in Section 2. In Section 3, the antenna results are discussed. Finally the paper is concluded in Section 4.

\section{Material and Method}

\subsection{Antenna Design Details}

The proposed antenna is mounted on a FR-4 substrate with a thickness of $\mathrm{h}=1.6 \mathrm{~mm}$ and a dielectric constant of $\varepsilon_{\mathrm{r}}=4.3$ and a loss tangent of $\tan \delta=0.025$. The copper metal is $35 \mu \mathrm{m}$. The planned antenna has a $30 \times 30 \mathrm{~mm}^{2}$ footprint. The antenna is fed by a $50 \Omega$ microstrip transmission line with a width of $7.25 \mathrm{~mm}$ and a length of $1.5 \mathrm{~mm}$ that is extended to touch the patch and attached directly to the radiating structure. Figure 1 depicts the proposed antenna architecture in details. Table 1 contains all of the geometrical aspects of Figure 1.

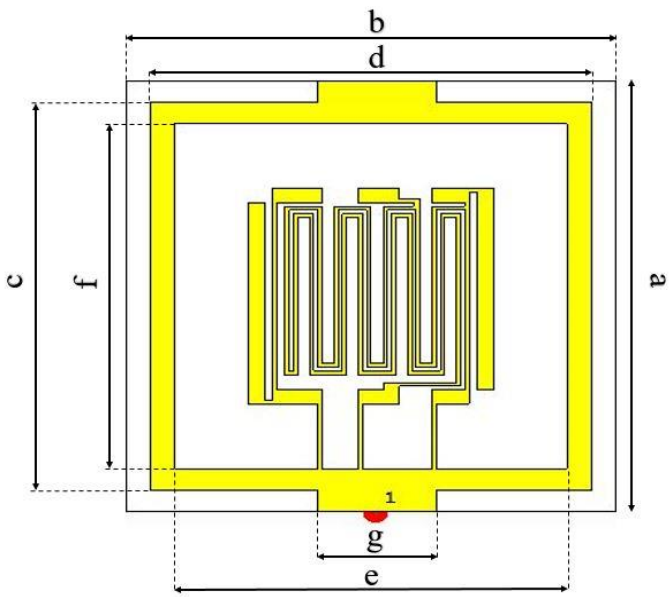

(a)

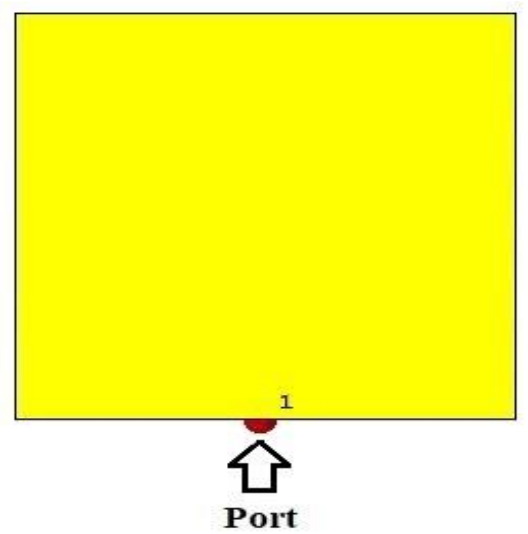

(b)

Figure 1. Antenna design: (a) Front view and (b) Back view.

Table 1. Geometrical details of the proposed antenna.

\begin{tabular}{cc}
\hline Parameter & $\begin{array}{c}\text { Value } \\
(\mathbf{m m})\end{array}$ \\
\hline A & 30 \\
B & 30 \\
C & 27 \\
D & 27 \\
E & 24 \\
F & 24 \\
G & 7.25 \\
\hline
\end{tabular}

\subsection{Antenna Optimization Study}

The proposed antenna dimensions are parametrically studied after invoking a neural network architecture. In this network, a knowledge-based hybrid neural network (KBHNN) model is for designing of microstrip antennas which is used for ISM band applications. In Figure 2, a synthesis model is defined as to obtain dimensions (W, L) of the antenna while providing the resonant frequency $\left(f_{\mathrm{r}}\right)$, height of the dielectric substrate $(h)$, quality factor $(Q)$, bandwidth (B.W), and return loss spectra $\left(S_{11}\right)$ at the input of the ANN model. 


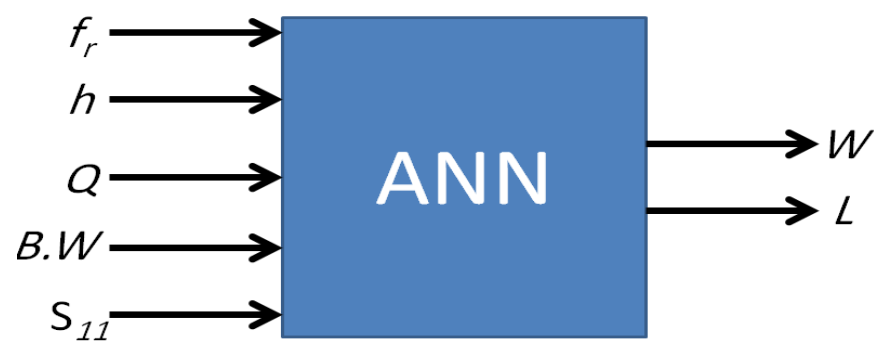

Figure 2. The synthesis of microstrip patch using ANN model.

It's worth noting that neural network models are extremely versatile methods for designing highly nonlinear devices. In our case, we used a neural network model to calculate the proposed patch's key dimensions, including the distance between internal dimension data. Bandwidth (B.W), resonant frequency $\left(f_{\mathrm{r}}\right)$, gain $(\mathrm{G})$, quality factor $(\mathrm{Q})$, and S11 magnitude have all been used as input to the model. As shown in Figure 3, the network architecture consists of one hidden layer and tow neurons in the output layer.

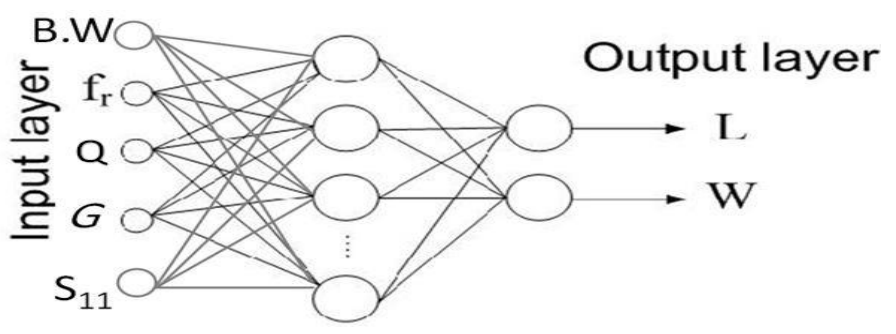

Figure 3. Architecture of neural network model.

As training data for the proposed ANN, about 50 samples are collected by varying the dimensions of the proposed microstrip patch antenna using the CST MWS software package [14], as shown in Table 2. As will be shown later, this information is used to synthesis a patch antenna.

Table 2. Input antenna performance.

\begin{tabular}{ccccccc}
\hline $\boldsymbol{L} / \mathbf{m m}$ & $\boldsymbol{W} / \mathbf{m m}$ & $\begin{array}{c}\boldsymbol{f}_{\mathbf{r}} / \\
\mathbf{G H z}\end{array}$ & $\begin{array}{c}\left|\mathbf{S}_{\mathbf{1 1}}\right| \boldsymbol{d B} \\
\mathbf{d B}\end{array}$ & $\boldsymbol{G} / \mathbf{d B}$ & $\begin{array}{c}\mathbf{Q} / \\
\boldsymbol{\%}\end{array}$ & $\begin{array}{c}\mathbf{B . W} / \\
\mathbf{M H z}\end{array}$ \\
\hline 70 & 63 & 0.1091 & 24.5 & 0.1091 & 12 & 10 \\
69 & 62 & 0.112 & 22.1 & 0.112 & 11 & 10 \\
68 & 61 & 0.115 & 22.4 & 0.115 & 11 & 11 \\
67 & 60 & 0.106 & 23.1 & 0.106 & 12 & 12 \\
66 & 59 & 0.115 & 24.7 & 0.115 & 15 & 11 \\
65 & 58 & 0.111 & 23.9 & 0.111 & 22 & 9 \\
64 & 57 & 0.123 & 26.9 & 0.123 & 9 & 10 \\
63 & 56 & 0.193 & 28.1 & 0.193 & 8 & 11 \\
62 & 55 & 0.191 & 28.4 & 0.191 & 21 & 12 \\
61 & 54 & 0.103 & 22.8 & 0.103 & 31 & 11 \\
60 & 53 & 0.109 & 22.3 & 0.109 & 9 & 11 \\
59 & 52 & 0.108 & 25.3 & 0.108 & 12 & 7 \\
58 & 51 & 0.121 & 27.2 & 0.121 & 11 & 9 \\
57 & 50 & 0.111 & 22.9 & 0.111 & 13 & 8 \\
56 & 49 & 0.156 & 26.3 & 0.156 & 17 & 9 \\
55 & 48 & 0.116 & 23.1 & 0.116 & 15 & 5 \\
54 & 47 & 0.182 & 22.9 & 0.182 & 10 & 6 \\
53 & 46 & 0.174 & 23.0 & 0.174 & 9 & 4 \\
52 & 45 & 0.091 & 23.1 & 0.091 & 16 & 10 \\
51 & 44 & 0.098 & 23.1 & 0.098 & 13 & 11 \\
50 & 43 & 0.092 & 23.9 & 0.092 & 10 & 13
\end{tabular}

\begin{tabular}{lcccccc}
49 & 42 & 0.109 & 24.1 & 0.109 & 11 & 9 \\
48 & 41 & 0.106 & 23.9 & 0.106 & 12 & 10 \\
47 & 40 & 0.110 & 22.4 & 0.110 & 11 & 11 \\
46 & 39 & 0.122 & 22.4 & 0.122 & 7 & 4 \\
45 & 38 & 0.133 & 27.3 & 0.133 & 7 & 7 \\
44 & 37 & 0.124 & 27.9 & 0.124 & 9 & 5 \\
43 & 36 & 0.111 & 24.1 & 0.111 & 11 & 10 \\
42 & 35 & 0.110 & 27.8 & 0.110 & 13 & 4 \\
41 & 34 & 0.113 & 27.4 & 0.113 & 12 & 7 \\
40 & 33 & 0.091 & 26.3 & 0.091 & 10 & 10 \\
39 & 32 & 0.094 & 25.6 & 0.094 & 7 & 6 \\
38 & 31 & 0.092 & 26.1 & 0.092 & 11 & 8 \\
37 & 30 & 0.109 & 25.3 & 0.109 & 9 & 4 \\
36 & 29 & 0.101 & 25.9 & 0.101 & 7 & 6 \\
35 & 28 & 0.105 & 25.2 & 0.105 & 12 & 2 \\
34 & 27 & 0.189 & 24.2 & 0.189 & 11 & 12 \\
33 & 26 & 0.188 & 23.4 & 0.188 & 10 & 11 \\
32 & 25 & 0.177 & 24.4 & 0.177 & 9 & 7 \\
31 & 24 & 0.109 & 27.8 & 0.109 & 12 & 6 \\
30 & 23 & 0.110 & 27.3 & 0.110 & 11 & 2 \\
29 & 22 & 0.112 & 27.0 & 0.112 & 9 & 4 \\
28 & 21 & 0.195 & 24.9 & 0.195 & 4 & 8 \\
27 & 20 & 0.196 & 25.2 & 0.196 & 5 & 9 \\
26 & 19 & 0.179 & 25.1 & 0.179 & 8 & 5 \\
\hline
\end{tabular}

The ANN training loss results for the proposed microstrip patch antenna synthesis is shown in Figure 4. It shows that 100 epochs are required for ANN training loss to get reduced from 100 to nearly $10^{-2}$.

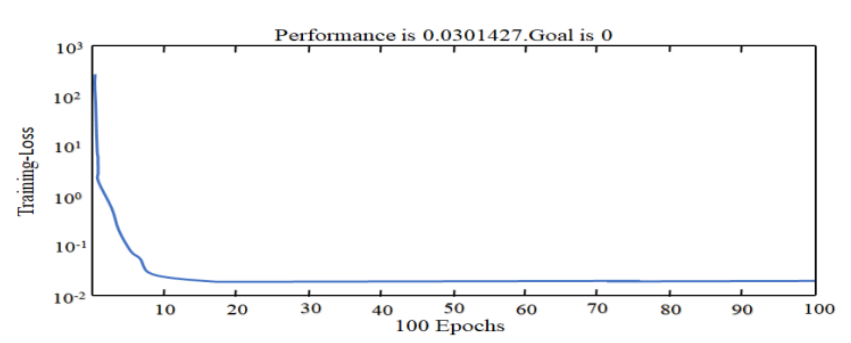

Figure 4. ANN training results for synthesis of microstrip patch antenna.

\section{Results and Discussion}

The proposed neural network model is applied for given $f_{\mathrm{r}}=$ $0.63 \mathrm{GHz}$ with $\left|\mathrm{S}_{11}\right|=16 \mathrm{~dB}$ and a bandwidth of $0.6 \mathrm{GHz}$ to $0.65 \mathrm{GHz}$ with $\mathrm{G}=1.5 \mathrm{dBi}$. The antenna dimensions obtained through the network simulation model are summarized in Table 3. It is seen that when the percentage errors are calculated and compared to the simulated ones, it seems there is a very good fit corresponding to 0.044 percent error.Therefore, according to the obtained dimensions, the proposed antenna performance is validated in another software package of HFSS simulator [15]. The simulated results from both software packages show excellent agreement as seen in Figure 5 for the $S_{11}$ and gain spectra.

Table 3. Obtained antenna dimensions from CST MWS and HFSS with respect to ANN model.

\begin{tabular}{ccccc}
\hline Dimension/ mm & CST & HFSS & ANN & Error \\
\hline L & 30 & 30.5 & 31.3 & 0.044 \\
W & 24 & 23.4 & 22.9 & 0.041 \\
\hline
\end{tabular}



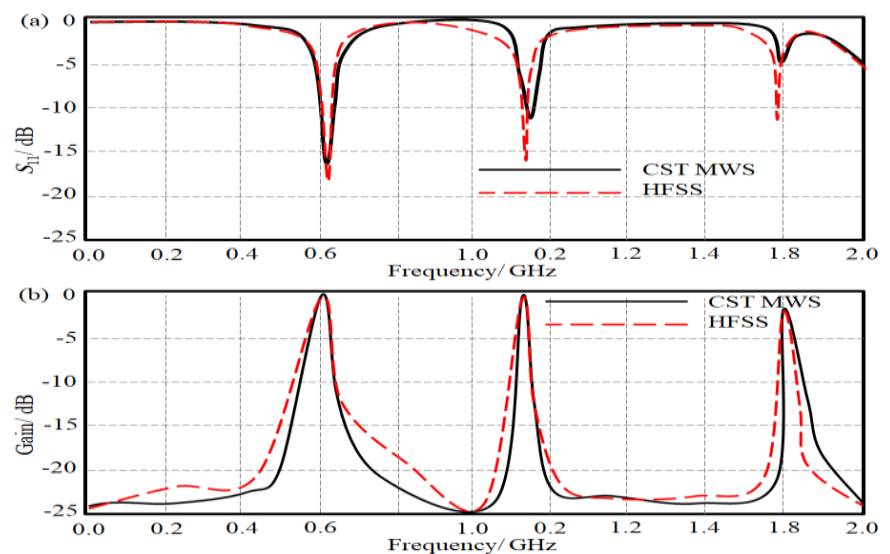

Figure 5. Validated results: (a) S11 and (b) gain spectra.

\section{Conclusions and Recommendations}

A design of a microstrip antenna is proposed based on MTM. The proposed antenna is designed to show a frequency resonance at $0.63 \mathrm{GHz}$ with $\left|\mathrm{S}_{11}\right|=16 \mathrm{~dB}$ and a bandwidth of $0.6 \mathrm{GHz}$ to $0.65 \mathrm{GHz}$ with $\mathrm{G}=1.5 \mathrm{dBi}$. Therefore, a neural network is proposed and parametric study is invoked based on CST MWS. The obtained results from CST MWS are used as training data to optimize the antenna dimensions at the desired performance. The antenna dimensions are calculated based on the proposed neural network. The obtained design performances are validated numerically using HFSS simulator. It is believed that the neural network models could be the alternative candidate for antenna design to avoid complex and long lasting computations.

\section{References}

[1] Mahmood, S.N., Ishak, A.J., Saeidi, T., Soh, A.C., Jalal, A., Imran, M.A., Abbasi, Q.H. (2021) Full ground ultrawideband wearable textile antenna for breast cancer and wireless body area network applications. Micromachines, 12, 322. https://doi.org/10.3390/ mi12030322.

[2] Ali, J.K., Ahmed, E.S. (2012) A new fractal based printed slot antenna for dual band wireless communication applications. in Proc. Progress in Electromagnetics Research Symp., Kuala Lumpur, Malaysia.

[3] Ali, J., Abdulkareem, S., Hammoodi, A., Salim, A., Yassen, M., Hussan, M., \& Al-Rizzo, H. (2016) Cantor fractal-based printed slot antenna for dual-band wireless applications. International Journal of Microwave and Wireless Technologies, 8(2), 263-270.

[4] Elwi, T. A. (2019) Printed microwave metamaterialantenna circuitries on nickel oxide polymerized palm fiber substrates. Sci. Rep., Vol. 9, No. 2174, 1-14.

[5] Elwi, T. A. (2019) Novel UWB printed metamaterial microstrip antenna based organic substrates for RF-energy harvesting applications. International Journal of Electronics and Communications, Vol. 101, No. 9, 1-10.

[6] Elwi, T. A. and B. A. Ahmed (2018) A fractal metamaterial based printed dipoles on a nickel oxide polymer palm fiber substrate for Wi-Fi applications. International Journal of Electronics and Communications, Vol. 96, No. 23, 122 129.

[7] Hatem, G. M., A. J. Salim, T. A. Elwi, et al. (2019) Wunderlich curve fractal dipole antenna for dualband wearable RFID applications. Journal of Engineering and Applied Sciences, Vol. 14, No. 4, 1093-1099.

[8] Elwi, T. A., A. I. Imran, and Y. Alnaiemy (2015) A miniaturized lotus shaped microstrip antenna loaded with EBG structures for high gain-bandwidth product applications. Progress in Electromagnetics Research $C$, Vol. 60, 157-167.

[9] Elwi, T. A. (2018) A slotted lotus-shaped microstrip antenna based EBG structures. Wireless Communication Technology, Vol. 2, No. 1, 1-24.

[10] Imran, A. I. and T. A. Elwi (2017) A cylindrical wideband slotted patch antenna loaded with frequency selective surface for MRI applications. Eng. Sci. \& Tech., an Int. Jou., Vol. 20, No. 3, 990-996.

[11] Elwi, T. A., Z. A. Al-Hussain, and Tawfeeq O.A. (2019) Hilbert metamaterial printed antenna based on organic substrates for energy harvesting. IET Micr., Ant. \& Prop., Vol. 10, No. 2, 1-8.

[12] Elwi, T. A., D. A. Jassim, and H. H. Mohammed (2020) Novel miniaturized folded UWB microstrip antenna-based metamaterial for RF energy harvesting. Int. J. Commun. Syst., Vol. 1, No. e4305, 1-15.

[13] Elwi, T. A. (2017) Electromagnetic band gap structures based an ultra-wideband microstrip antenna. Microwave and Optical Letters, 59(4), 827-834.

[14] CST Microwave Studio (CST MWS). (2020) http://www.cst.com.

[15] High Frequency Structure Simulator (HFSS). (2020) http://www.ansoft.com. 